\title{
PENERAPAN KOMBINASI MODEL KOOPERATIF DAN DISCOVERY UNTUK MENINGKATKAN INTERAKSI SOSIAL DAN AKTIVITAS BELAJAR PKN SISWA SEKOLAH DASAR
}

\author{
Liswati \\ SDN 04 Pangkalan Buton \\ Email: liswatisdn04pangkalanbuton@gmail.com
}

\begin{abstract}
Abstrak
Hasil survey di lapangan menunjukkan bahwa kondisi hasil belajar siswa dalam mata pelajaran PKn di kelas V SDN 04 Pangkalan Buton belum sesuai dengan harapan guru. Hal ini di tunjukkan dari hasil pembelajaran PKn yang telah dilakukan selama ini dengan menggunakan model pembelajaran ceramah. antara lain : (1) siswa kesulitan untuk memahami konsep akademik dalam menggambarkan sesuatu yang abstrak; (2) suasana belajar menjadi membosankan bagi siswa. Apakah dengan kombinasi model pembelajaran kooperatif dan discovery di kelas V SDN 04 Pangkalan Buton tahun ajaran 2019/2020 dapat meningkatkan interaksi sosial dan aktivitas belajar siswa ?. Pada hasil belajarpun mengalami peningkatan, kalau kita melihat dari data hasil belajar siswa serta membandingkan dari pra PTK, samapi dengan pelaksanaan siklus II sebagai kelanjutan dari pelaksanaan perbaikan dari siklus I, yang mana pada hasil belajar pada pra PTk siswa mendapatkan hasil belajar kategori kurang ada 4 orang $(21 \%)$, setelah melaksanakan PTK pada siklus I menjadi 3 orang $(16 \%)$ dan pada siklus II siswa yang tergolong nilai hasil pembelajarannya kurang menjadi $0(0 \%)$
\end{abstract}

\section{Kata Kunci : Metode, Kooperatif, Discovery}

\section{PENDAHULUAN}

Hasil survey di lapangan menunjukkan bahwa kondisi hasil belajar siswa dalam mata pelajaran PKn di kelas V SDN 04 Pangkalan Buton belum sesuai dengan harapan guru. Hal ini di tunjukkan dari hasil pembelajaran PKn yang telah dilakukan selama ini dengan menggunakan model pembelajaran ceramah. Adapun sejumlah permasalahan yang dihadapi dalam penerapan model pembelajaran ceramah ini, antara lain : (1) siswa kesulitan untuk memahami konsep akademik dalam menggambarkan sesuatu yang abstrak; (2) suasana belajar menjadi membosankan bagi siswa; (3) tidak adanya interaktif sosial siswa dengan siswa lainnya; (4) siswa kesulitan dalam mengungkapkan ide/gagasan yang dimilikinya; (5) guru sulit mengukur pemahaman serta penguasaan siswa terhadap materi yang diajarkan; (6) waktu yang diperlukan untuk menerangkan materi ajar lebih lama.

Suasana belajar seperti ini semakin menjauhkan peran PKn dalam upaya penerapan nilai-nilai $\mathrm{PKn}$ didalam bermasyarakat serta bersosialisasi dengan lingkungan sekitarnya. Kondisi pembelajaran PKn yang cenderung bersifat guru sentris sehingga siswa hanya menjadi objek pembelajaran, sehingga guru merasa telah mentransfer pengetahuan kepada siswa tetapi siswa belum merasa belajar.

Dengan analisis permasalahan tersebut dapatlah diformulasikan solusi masalah yang dihadapi dengan cara, merubah penggunaan metode pembelajaran yang lain yang lebih memfokuskan keaktivan siswa dalam menyelesaikan suatu masalah maupun pengungkapan ide-idenya, sehingga dalam hal ini siswa berperan sebagai subjek.

Berdasarkan latar belakang diatas penulis berdiskusi dengan teman sejawat pendamping penelitian, dan melalaui diskusi tersebut didapatlah beberapa masalah yang teridentifikasi pada proses pembelajaran PKn Kelas V SDN 04 Pangkalan Buton yaitu : (1) Siswa tampak tidak tertarik akan materi yang disampaikan. (2) Siswa tampak tidak aktif saat pembelajaran berlangsung, hal ini dapat dilihat dari kurangnya minat siswa untuk 
menjawab dan mengajukan pertanyaan. (3) Hasil belajar siswa rendah

Berdasarkan uraian latar belakang dan identifikasi permasalahan diatas, maka rumusan masalah dalam penelitian ini adalah sebagai berikut : (1) Apakah dengan kombinasi model pembelajaran kooperatif dan discovery di kelas V SDN 04 Pangkalan Buton tahun ajaran 2019/2020 dapat meningkatkan interaksi sosial dan aktivitas belajar siswa ? (2) Seberapa peningkatan prestasi / hasil belajar PKn siswa kelas V SDN 04 Pangkalan Buton tahun ajaran 2019/2020 dengan menerapkan Metode pembelajaran kooperatif dan discovery ? (3) Hambatan-hambatan apa saja yang ditemukan pada penerapan model pembelajaran kooperatif dan discovery di SDN 04 Pangkalan Buton?

Tujuan utama yang ingin dicapai dari penelitian tindakan kelas ini adalah : (1) Meningkatkan daya interaksi sosial siswa kelas V SDN 04 Pangkalan Buton tahun ajaran 2019/2020. (2) Meningkatkan Aktivitas belajar siswa kelas V SDN 04 Pangkalan Buton tahun ajaran 2019/2020. (3) Meningkatnya prestasi belajar siswa kelas V SDN 04 Pangkalan Buton tahun ajaran 2019/2020. (4) Mengetahui hambatan-hambatan yang dihadapi dalam penerapan model pembelajaran kooperatif dan discovery, di kelas V SDN 04 Pangkalan Buton tahun ajaran 2019/2020.

Manfaat yang akan diperoleh dari kegiatan penelitian ini adalah untuk : (1) Bagi guru, khususnya guru yang mengajarkan PKn SD kelas $\mathrm{V}$. penelitian ini sangat bermanfaat dalam meningkatkan wawasan dan keterampilan mereka dalam melaksanakan pembelajaran PKn di kelas V $\mathrm{SD}$, sehingga nantinya mereka dapat mengantisipasi sedini mungkin berbagai permasalahan yang berkaitan dengan tugas dan profesinya, serta meningkatkan produktivitasnya sebagai pengembang dan pelaksana kurikulum; (2) Bagi Sekolah Dasar, khususnya SDN 04 Pangkalan Buton, hasil penelitian ini menjadiupaya penjajagan untuk memungkinkan menjadi seorang guru yang profesional; (3) Bagi siswa, khususnya kelas V SDN 04 Pangkalan Buton tahun ajaran 2019/2020 yang dijadikan obyek penelitian, akan sangat bermanfaat dalam meningkatkan kegairahaan dan pengalaman belajar yang nantinya dapat meningkatkan daya interaksi sosial antar siswa dan di masyarakat, aktivitas serta prestasi belajar mereka ; (4) Bagi penelitian ini sangat bermanfaat pula bagi kalangan masyarkat luas, sehingga tenaga dan berbagai potensi yang ada dapat disumbangkan kepada khalayak luas, khususnya yang berkenaan dengan sektor pendidikan.

Menurut pengertian secara psikologis belajar merupakan suatu proses perubahan, yaitu perubahan tingkah laku sebagai hasil dan interaksi dengan lingkungannya dalam memenuhi kebutuhan hidupnya. Perubahan-perubahan tersebut akan nyata dalam seluruh aspek tingkah laku. Belajar merupakan suatu proses usaha yang dilakukan seseorang untuk memperoleh suatu perubahan tingkah laku yang baru secara keseluruhan, sebagai hasil pengalaman sendiri dalam interaksi dengan lingkungannya.1 Durton mengartikan belajar adalah suatu perubahan dalam diri individu sebagai hasil interaksi lingkungannya untuk memenuhi kebutuhan dan menjadikannya lebih mampu melestarikan lingkungan secara memadai. "Learning is a change the individual due to interaction of that individual and his environments which fills a need and makes him capable of dealing adequality with his environment".

Menurut Hilgrad dan Bower, belajar (to learn) memiliki arti : to gain knowledge, comprehension, or mastery of trough experience or study, to fix in the mind or memory; memorize; to acquire trough experience, to become in forme of to find out. Menurut definisi tersebut, belajar memiliki pengertian memperoleh pengetahuan atau menguasai pengetahuan melalui pengalaman, mengingat, menguasai pengalaman, dan mendapatkan informasi atau menemukan. Dengan demikian, belajar memiliki arti dasar adanya aktivitas atau kegiatan dan penguasaan tentang sesuatu.

Sedangkan menurut James O. Wittaker mengemukakan bahwa belajar adalah proses dimana tingkah laku ditimbulkan atau diubah melalui latihan atau pengalaman. Dari pendapatpendapat diatas, dapat disimpulkan bahwa belajar adalah suatu proses yang ditandai dengan adanya perubahan pada diri seseorang. Perubahan sebagai hasil dari berbagai bentuk seperti perubahan pengetahuan, pemahaman sikap, tingkah laku, ketrampilan, kecakapan, kebiasaan serta perubahan 
aspek-aspek lain yang ada pada individu yang belajar. Proses terjadinya belajar sangat sulit diamati. Karena itu orang cenderung melihat tingkah laku manusia untuk disusun. menjadi pola tingkah laku yang akhirnya tersusunlah suatu model yang menjadi prinsip-prinsip belajar yang bermanfaat sebagai bekal untuk memahami, mendorong dan memberi arah kegiatan belajar.

Prinsip-prinsip Belajar Prinsip-prinsip belajar yang dapat dilaksanakan dalam situasi dan kondisi yang berbeda dan oleh setiap peserta didik secara individual adalah sebagai berikut: 1) Berdasar prasyarat yang diperlukan untuk belajar. Dalam belajar peserta didik diusahakan partisipasi aktif, meningkatkan minat dan membimbing untuk mencapai tujuan intruksional. 2) Sesuai hakikat belajar. Belajar adalah proses kontinguitas (hubungan antara pengertian yang lain) sehingga mendapat pengertian yang diharapkan stimulus yang diberikan dapat menimbulkan respon yang diharapkan. 3) Sesuai materi atau bahan yang akan dipelajari. Belajar bersifat keseluruhan dan materi itu harus memiliki struktur penyajian yang bisa ditangkap pengertiannya. 4) Syarat keberhasilan belajar Belajar memerlukan sarana yang cukup, sehingga peserta didik dapat belajar dengan tenang.

Beberapa teori belajar yang yang relevan dan dapat diterapkan dalam kegiatan pembelajaran yang akan dikembangkan antara lain: 6 Pertama, menurut teori belajar behaviorisme, manusia sangat dipengaruhi oleh kejadian-kejadian di dalam lingkungannya yang akan memberikan pengalamanpengalaman belajar. Teori ini menekankan pada apa yang dilihat yaitu tingkah laku. Kedua, menurut teori belajar kognitif, belajar adalah pengorganisasian aspek-aspek kognitif dan persepsi untuk memperoleh pemahaman. Teori ini menekankan pada gagasan bahwa bagian suatu situasi saling berhubungan dalam konteks situasi secara keseluruhan. Ketiga, menurut teori belajar humanisme, proses belajar harus dimulai dan ditunjukan untuk kepentingan memanusiakan manusia, yaitu mencapai aktualisasi diri peserta didik yang belajar secara optimal.

Keempat, menurut teori belajar sibernetik, belajar adalah mengolah informasi (pesan pembelajaran), proses belajar sangat ditentukan oleh sistem informasi. Kelima, menurut teori belajar konstruktivism, belajar adalah menyusun pengetahuan dari pengalaman konkret, aktivitas kolaborasi, refleksi serta interpretasi. Adapun teori belajar yang melatarbelakangi dalam penelitian ini terkait dengan penggunaan media pembelajaran adalah teori belajar behavioristik, dimana rangsangan dari luar/ lingkungan sekitar mempengaruhi terhadap proses memperoleh suatu pengetahuan. Edward L. Thorndike mengemukakan beberapa hukum belajar yang dikenal sebagai sebutan law of effect. Menurut hukum ini belajar akan lebih berhasil bila respon peserta didik terhadap suatu stimulus segera diikuti dengan rasa senang atau kepuasan. Teori belajar stimulus-respon yang dikemukakan oleh Thorndike ini disebut juga koneksionisme. Teori ini menyatakan bahwa pada hakikatnya belajar merupakan proses pembentukan hubungan antara stimulus dan respon. Berdasarkan teori tersebut dalam penelitian ini akan dianalisis penggunaan media sebagai stimulus. Thorndike mengemukakan pula bahwa kualitas dan kuantitas hasil belajar peserta didik tergantung dari kualitas dan kuantitas

Stimulus- Respon (S-R) dalam pelaksanaan kegiatan belajar peserta didik. Menurut Brunner ada tiga tingkatan utama modus belajar, yaitu pengalaman langsung (enactive), pengalaman piktorial/ gambar (iconic), dan pengalaman abstrak (symbolic). 7 Uraian diatas memberikan petunjuk bahwa agar proses belajar mengajar dapat berjalan dengan baik, peserta didik sebaiknya diajak untuk memanfaatkan semua alat inderanya. Guru berupaya menampilkan rangsangan (stimulus) yang dapat di proses dengan berbagai indera. Semakin banyak alat indera yang digunakan untuk menerima dan mengolah informasi semakin besar kemungkinan informasi tersebut dimengerti dan dapat dipertahankan dalam ingatan. Dengan demikian diharapkan peserta didik akan dapat menerima dan menyerap dengan mudah dan baik pesan-pesan dalam materi yang disajikan

Pembelajaran adalah suatu usaha untuk membuat peserta didik belajar atau suatu kegiatan untuk membelajarkan peserta didik. Dengan kata lain, pembelajaran merupakan suatu upaya menciptakan kondisi agar terjadi kegiatan belajar. Dalam hal ini pembelajaran diartikan juga sebagai usaha-usaha yang terencana dalam memanipulasi sumber-sumer belajar agar terjadi proses belajar dalam diri peserta didik. Menurut Warsita pembelajaran adalah suatu usaha untuk membuat 
peserta didik belajar atau suatu kegiatan untuk membelajarkan peserta didik.

Model pembelajaran koopertaif adalah suatu proses kegiatan pembelajaran yang dilakukan dengan cara berkelompok untuk bekerjasama saling membantu dalam merumuskan konsep, menyelesaikan persoalan atau inkuiri, menurut kelompok terdiri dari 4-5 orang siswa heterogen (kemampuan, gender, karakter), ada kontrol dan fasilitasi serta meminta tanggungjawab hasil kelompok berupa laporan atau presentasi.

Pembelajaran kooperatif ini sesuai dengan fitrah manusia sebagai makhluk sosial yang penuh ketergantungan dengan orang lain, mempunyai tujuan dan tanggungjawab bersam, pembagian tugas dan rasa senasib. Dengan memanfaatkan kenyataan itu, belajar berkelompok secara kooperatif, siswa dilatih dan dibiasakan untuk saling berbagi (sharing) pengetahuan, pengalaman, tugas, dan tanggungjawab., karena kooperatif merupakan miniatur dari hidup bermasyarakat dan belajar menyadari kekurangan dan kelebihan masing-masing.

Pengertian tentang Discovery, menurut Sund adalah suatu proses mental dimana siswa mampu mengasilmilasikan sesuatu konsep atau prinsip. Proses mental tersebut adalah mengamati, mencermati, mengerti, menggolong-golongkan, membuat dugaan, menjelaskan, mengukur, membuat kesimpulan dan sebagainya (Roestitah, 2001:20). Sedangkan menurut Jerome Bruner " penemuan adalah suatu proses dalam mendekati permasalahan yang natinya permasalahan tersebut dapat dicarikan solusi oleh siswa, sedangkan guru sebagai fasilitator dan sebagai pembimbing siswa bila diperlukan.

Dari pendapat diatas dapat disimpulkan bahwa model penemuan terbimbing (Discovery) adalah model pembelajaran yang dimana siswa berpikir sendiri sehingga dapat menemukan prinsip umum yang diingikan dengan bimbingan dan petunjuk dari guru berupa pertanyaan-pertanyaan yang mengarahkan.

Langkah-langkah model pembelajaran penemuan terbimbing (Discovery) yang efeketif menurut Markaban (2006:16) adalah sebagai berikut : (1) Merumuskan masalah yang akan diberikan kepada siswa dengan data secukupnya, perumusan harus jelas, hindari pernyataan yang dapat menimbulkan salah tafsir sehingga arah yang di tempuh siswa tidak salah; (2) Dari data yang diberikan guru, siswa menyusun, memproses, mengorganisir dan menganalisis data tersebut. Siswa menyusun konjektur (prakiraan) dari hasil analisis yang dilakukannya. Sesudah siswa menemukan apa yang dicari, hendaknya guru menyediakan soal latihan atau soal tambahan untuk memeriksa apakah penemuan itu benar. (2) Memperhatikan langkah-langkah model pembelajaran

Discovery diatas dapat disimpulkan kelebihan dan kekurangan yang dimilikinya antara lain : (1) Kelebihan model Discovery (penemuan terbimbing) adalah ; (a) Siswa dapat berpartisipasi aktif dalam pembelajaran yang disajikan (b) Menumbuhkan sekaligus menanamkan sikap Inqury (mencari temukan). (c) Memberikan wahana interaksi siswa dengan siswa lain, maupun siswa dengan guru. dengan demikian siswa juga terlatih untuk mampu mengungkapkan ide-ide yang dimilikinya. (d) Lama membekas karena siswa dilibatkan langsung dalam proses menemukan. (2) Kekurangan model pembelajaran kooperatif (CL, Cooperative Learning) adalah ; (a) Untuk materi tertentu, waktu yang diperlukan lebih lama. (b) Tidak semua siswa dapat mengikuti pelajaran dengan cara ini. (c) Tidak semua topik cocok disampaikan dengan model pembelajaran ini.

\section{METODE PENELITIAN}

Subyek penelitian ini dilakukan karena adanya permasalahan yang dihadapi guru dalam pembelajaran PKn di kelas V SDN 04 Pangkalan Buton, antara lain : siswa kurang aktif, aktivitas yang masih siswa rendah, serta hasil / prestasi belajar siswa belum optimal. 
Tabel 1. Jadwal Penelitian Tindakan Kelas

\begin{tabular}{|c|c|c|c|c|c|c|c|}
\hline \multirow[t]{2}{*}{ No } & \multirow{2}{*}{$\begin{array}{c}\text { Tempat } \\
\text { Pelaksanaan PTK }\end{array}$} & \multirow[t]{2}{*}{ Waktu Pelaksanaan } & \multirow[t]{2}{*}{ Kelas } & \multicolumn{3}{|c|}{ Jenis Kelamin } & \multirow[t]{2}{*}{ Mata Pelajaran } \\
\hline & & & & $\mathbf{L}$ & $\mathbf{P}$ & Jml & \\
\hline 1 & $\begin{array}{l}\text { SDN 04 Pangkalan } \\
\text { Buton. }\end{array}$ & $\begin{array}{c}\text { Tari Selasa, 10 September } \\
2019\end{array}$ & V & 13 & 6 & 19 & $\begin{array}{l}\text { PKn. } \\
\text { Siklus I }\end{array}$ \\
\hline 2 & $\begin{array}{l}\text { SDN } 04 \text { Pangkalan } \\
\text { Buton. }\end{array}$ & $\begin{array}{l}\text { Hari Selasa, } 15 \text { Oktober } \\
2019\end{array}$ & V & 13 & 6 & 19 & $\begin{array}{l}\text { PKn. } \\
\text { Siklus II }\end{array}$ \\
\hline
\end{tabular}

Sedangkan yang menjadi obyek dari penelitian ini adalah untuk mengetahui : 1) pengetahuan tentang nilai $\mathrm{PKn}$; 2) kualitas pelaksanaan perpaduan model pembelajaran kooperatif dengan model pembelajaran Discovery; 3) daya interaksi sosial siswa dengan siswa lain, siswa dengan guru; 4) aktivitas belajar siswa: 5) prestasi belajar siswa; 6) hambatan-hambatan yang dihadapi; 7) respon dari siswa.

Berdasarkan fokus masalah dan untuk ketuntasan keseluruhan tahapan yang telah dirancang, maka penelitian tindakan kelas dalam bentuk siklus dapat diuraikan sebagai berikut yaitu : (1) Siklus I : (a). Merencanakan. Merencanakan segala sesuatu yang terkait dengan pembelajaran : Menyusun skenario pembelajaran dalam bentuk rencana pelaksanaan pembelajaran, Membuat lembar observasi, Lembar penilaian proses aktivitas siswa, Lembar penilaian hasil belajar siswa, Lembar refleksi setelah melakukan pembelajaran, Meminta ijin kepala sekolah, Persiapan media pembelajaran, sumber dan penunjang pembelajaran. (b) Melaksanakan. Pada langkah kedua ini peneliti melaksanakan segala rencana yang telah disiapkan sebelumnya dalam kegiatan pembelajaran. Selama peneliti melaksanakan pembelajaran di kelas, pengamat atau teman sejawat memperhatikan proses pembelajaran secara seksama dari awal sampai akhir pertemuan dengan menggunakan lembar observasi. (c) Refleksi. Langkah ini bertujuan untuk mengetahui tentang hal-hal yang sudah dicapai dalam pelaksanaan tindakan, serta halhal yang merupakan penghambat terjadinya masalah kegagalan pada pelaksanaan tindakan untuk menentukan rencana perbaikan siklus berikutnya. Dari data-data yang diperoleh dalam siklus I tentunya belum dapat mencerminkan apa yang diharapkan,. Oleh karena itu peneliti bersama teman sejawat membicarakan dan memikirkan rencana tindakan selanjutnya, agar memperoleh hasil yang lebih optimal dari pembelajaran sebelumnya. (2) Siklus II :Merencanakan. Merencanakan dalam siklus II ini persiapannya sama seperti pada siklus I yaitu : Menyusun skenario pembelajaran dalam bentuk perbaikan rencana pelaksanaan pembelajaran, Membuat lembar observasi, Lembar penilaian proses aktivitas siswa, Lembar penilaian hasil belajar siswa, Lembar refleksi setelah melakukan pembelajaran, Meminta ijin kepala sekolah , Persiapan media pembelajaran, sumber dan penunjang pembelajaran. (b) Melaksanakan. Selanjutnya peneliti melaksanakan proese perbaikan PKn pada siklus II. Materi secara rinci berupa perbaikan rencana pelaksanaan pembelajaran. Selama proses perbaikan pembelajaran berlangsung, pengamat atau penilai atau teman sejawat juga melaksanakan pengamatan di kelas sampai akhir dengan menggunakan instrumen observasi. (c) Refleksi. Temuan yang dialami pada siklus II ternyata banyak mengalami perubahan dan perkembangan kemajuan yang sangat berarti. Siswa sudah mulai suka dan berani dalam mengajukan pertanyaan yang terkait dengan materi pembelajaran, dengan demikian interaksi siswa dengan siswa, siswa dengan guru, aktivitas siswa dan prestasi belajar siswa jadi sesuai dengan yang diharapkan.

Data adalah hasil belajar siswa yang diambil dari proses pembelajaran dan hasil pembelajaran melalui: (1) Lembar observasi keaktivan siswa. (2) Hasil evaluasi (terlampir). Dalam penelitian ini, keberhasilan penelitian apa bila hasil tes siswa sudah berada dalam tingkat yang ditetapkan. Dalam penelitian ini ketercapaian dapat dilihat dari 
interval dalam katagori baik (interval nilai 60 79).

\section{HASIL PENELITIAN DAN PEMBAHASAN Hasil Penelitian}

Berdasarkan rumusan masalah yang sudah dipaparkan pada bab pendahuluan, maka paparan hasil penelitian mengacu pada permasalahan yaitu : 1) interaksi siswa; 2) aktivitas belajar siswa; 3) prestasi belajar siswa, 4) respon siswa, dengan penerapan model pembelajaran kooperatif dan
Discovery dalam mata pelajaran PKn di kelas V SDN 04 Pangkalan Buton tahun ajaran 2019/2020.

Data interaksi dan aktivitas siswa diperoleh dengan menggunakan lembar / instrumen penilaian proses pembelajaran pada pra PTK, siklus I kurang memuaskan. Hali ini dapat diketahui dari hasil data penilaian proeses pembelajaran yang telah dilakukan. berikut data penilaian proses pembelajaran untuk mengetahui daya interaksi, aktivitas belajar serta respon dari siswa.

Tabel 2. Data Penilaian Proses Pembelajaran Kelas V SDN 04 Pangkalan Buton Mata Pelajaran Pkn

\begin{tabular}{|c|c|c|c|c|c|c|c|c|c|c|}
\hline \multirow{3}{*}{ No } & \multirow{3}{*}{ Nama Siswa } & \multicolumn{9}{|c|}{ Aspek Yang Dinilai } \\
\hline & & \multicolumn{3}{|c|}{ Nilai } & \multicolumn{3}{|c|}{ Minat } & \multicolumn{3}{|c|}{ Sikap } \\
\hline & & $\begin{array}{c}\text { Pra } \\
\text { PTK }\end{array}$ & $\begin{array}{c}\text { Siklus } \\
\text { I }\end{array}$ & Siklus II & $\begin{array}{l}\text { Pra } \\
\text { PTK }\end{array}$ & $\begin{array}{c}\text { Siklus } \\
\text { I }\end{array}$ & Siklus II & $\begin{array}{c}\text { Pra } \\
\text { PTK }\end{array}$ & $\begin{array}{c}\text { Siklus } \\
\text { I }\end{array}$ & Siklus II \\
\hline 1 & AS & 5 & 5,8 & 6,6 & 5,5 & 5,7 & 7 & 4,5 & 5 & 6,5 \\
\hline 2 & ARO & 5,5 & 6,6 & 7,2 & 6 & 6,7 & 7,7 & 5,7 & 6 & 7 \\
\hline 3 & $\mathrm{BH}$ & 5,3 & 6,2 & 7,4 & 5,8 & 5,7 & 6,7 & 5,1 & 5,5 & 6,5 \\
\hline 4 & $\mathrm{BS}$ & 5,4 & 6 & 7 & 5,9 & 6,3 & 7 & 5,7 & 6 & 7 \\
\hline 5 & $\mathrm{BM}$ & 6 & 6,8 & 7,8 & 6,8 & 7,3 & 7,7 & 6 & 6,5 & 7,5 \\
\hline 6 & CA & 6,5 & 7,2 & 8,6 & 7 & 8 & 9 & 6,8 & 7 & 8 \\
\hline 7 & EN & 5,1 & 5,8 & 7 & 6,5 & 6,7 & 7 & 5,7 & 6 & 7 \\
\hline 8 & EA & 7 & 7,6 & 8,8 & 7,2 & 8 & 9 & 6,7 & 7 & 8 \\
\hline 9 & $E$ & 5,4 & 6,2 & 7,2 & 5,6 & 5,7 & 6,7 & 5,1 & 5,5 & 6 \\
\hline & FI & 4,9 & 5,8 & 6,8 & 5 & 5,3 & 6 & 4,5 & 5 & 6 \\
\hline & GF & 5,4 & 6 & 8 & 6,7 & 7 & 7,7 & 5,8 & 6,5 & 7 \\
\hline & GL & 6,5 & 7 & 8 & 6,9 & 7,3 & 8 & 5,9 & 6,5 & 7 \\
\hline & HDS & 6,3 & 7 & 8 & 6,8 & 7,3 & 7,7 & 6 & 6,5 & 7 \\
\hline & IF & 5,7 & 6,2 & 7 & 5,8 & 6,3 & 7 & 5 & 5,5 & 6,5 \\
\hline & Kartono & 5,5 & 6,2 & 7,2 & 5,6 & 6 & 6,7 & 4,9 & 5,5 & 7 \\
\hline & KSP & 6 & 6,8 & 8 & 6,8 & 7,7 & 8,3 & 5,8 & 6,5 & 7,5 \\
\hline & MOS & 5,9 & 6,4 & 7,2 & 6 & 6,7 & 7,3 & 5,5 & 6 & 7 \\
\hline 18 & $\mathrm{RS}$ & 6,6 & 7,4 & 8,2 & 7,1 & 7,7 & 8,7 & 6,7 & 7 & 7,5 \\
\hline & $\mathrm{ZM}$ & 5,6 & 6,2 & 7,2 & 5,8 & 6,3 & 7 & 5,7 & 6 & 7 \\
\hline & Jumlah & 103,3 & 123,2 & 143,2 & 112,1 & 127,7 & 142,2 & 108,3 & 115,5 & 153 \\
\hline & Rata-rata & 5,4 & 6,5 & 7,5 & 5,9 & 6,1 & 7,5 & 5,7 & 6,1 & 8,1 \\
\hline & Daya Serap & $54 \%$ & $65 \%$ & $75 \%$ & $59 \%$ & $61 \%$ & $75 \%$ & $57 \%$ & $61 \%$ & $81 \%$ \\
\hline
\end{tabular}

Keterangan. Per Item Nilai $x 10$

Dari data diatas dapat diuraikan dan digambarkan tentang peningkatan rata-rata daya

interaksi serta aktivitas kedalam tabel data per siklus sebagai berikut: 
Tabel 3. Pencapaian Ketuntasan Interaksi Dan Aktivitas Siswa Kelas V SDN 04 Pangkalan Buton Pada Siklus I

\begin{tabular}{lllllll}
\hline \multirow{2}{*}{ Rentang Nilai } & Kategori & \multicolumn{4}{c}{ Aspek Penilaian dalam Silkus I } \\
\cline { 2 - 6 } & & \multicolumn{2}{c}{ Nilai } & \multicolumn{2}{c}{ Minat } & \multicolumn{2}{c}{ Sikap } \\
\cline { 2 - 6 } & Jml Siswa & $\%$ & Jml Siswa & $\%$ & Jml Siswa & $\%$
\end{tabular}

\begin{tabular}{cccccccc}
\hline $90-100$ & Sangat Baik & & & & & \\
\hline $80-89,9$ & Baik & & & 2 & $10,5 \%$ & & \\
\hline $70-79,9$ & Cukup Baik & 5 & $26,3 \%$ & 6 & $31,6 \%$ & 3 & $15,8 \%$ \\
\hline $55-69,9$ & Cukup & 14 & $73,7 \%$ & 10 & $52,6 \%$ & 14 & $73,7 \%$ \\
\hline $40-54,9$ & Kurang & & & 1 & $5,3 \%$ & 2 & $10,5 \%$ \\
\hline $0-30,9$ & Sangat Kurang & & & & & & \\
\hline
\end{tabular}

Tabel 4. Pencapaian Ketuntasan Interaksi Dan Aktivitas Siswa Kelas V SDN 04 Pangkalan Buton Pada Siklus II

\begin{tabular}{|c|c|c|c|c|c|c|c|}
\hline \multirow{3}{*}{$\begin{array}{c}\text { Rentang } \\
\text { Nilai }\end{array}$} & \multirow{3}{*}{ Kategori } & \multicolumn{6}{|c|}{ Aspek Penilaian dalam Silkus II } \\
\hline & & \multicolumn{2}{|c|}{ Nilai } & \multicolumn{2}{|c|}{ Minat } & \multicolumn{2}{|c|}{ Sikap } \\
\hline & & Jml Siswa & $\%$ & $\begin{array}{c}\text { Jml } \\
\text { Siswa }\end{array}$ & $\%$ & Jml Siswa & $\%$ \\
\hline $90-100$ & Sangat Baik & & & 2 & $10,5 \%$ & & \\
\hline $80-89,9$ & Baik & 7 & $36,8 \%$ & 3 & $15,8 \%$ & 2 & $10,5 \%$ \\
\hline $70-79,9$ & Cukup Baik & 10 & $52,6 \%$ & 10 & $52,6 \%$ & 12 & $63,2 \%$ \\
\hline $55-69,9$ & Cukup & 2 & $10,5 \%$ & 4 & $21,1 \%$ & 5 & $26,3 \%$ \\
\hline $40-54,9$ & Kurang & & & & & & \\
\hline $0-30,9$ & Sangat Kurang & & & & & & \\
\hline
\end{tabular}

Pembahasan hasil penelitian berdasarkan sajian data yang ditampilkan pada table 5 dibawah ini yang menunjukan hasil belajar dari pra PTK sampai dengan Siklus II.

Tabel 5. Perolehan Hasil Belajar Mata Pelajaran Pkn Kelas V SDN Negeri 04 Pangkalan Buton

\begin{tabular}{llccc}
\hline \multirow{2}{*}{ No } & \multirow{2}{*}{ Nama Siswa } & Pra PTK & Siklus I & Siklus II \\
\cline { 3 - 5 } & AS & 55 & 58 & 65 \\
\hline 2 & ARO & 60 & 61 & 68 \\
\hline 3 & BH & 60 & 63 & 68 \\
\hline 4 & BS & 62 & 63 & 67 \\
\hline 5 & BM & 66 & 68 & 70 \\
\hline 6 & CA & 72 & 78 & 81 \\
\hline 7 & EN & 55 & 57 & 63 \\
\hline 8 & EA & 74 & 78 & 82 \\
\hline 9 & E & 50 & 53 & 60 \\
\hline 10 & FI & 50 & 53 & 62 \\
\hline 11 & GF & 65 & 68 & 73 \\
\hline 12 & GL & 67 & 70 & 75 \\
\hline 13 & HDS & 68 & 71 & 65 \\
\hline 14 & IF & 50 & 59 & \\
\hline
\end{tabular}




\begin{tabular}{llccc}
15 & Kartono & 48 & 52 & 63 \\
\hline 16 & KSP & 68 & 72 & 75 \\
\hline 17 & MOS & 60 & 65 & 69 \\
\hline 18 & RS & 70 & 75 & 79 \\
\hline 19 & ZM & 55 & 58 & 66 \\
\hline \multicolumn{2}{r}{ Jumlah Nilai } & 1155 & 1222 & 1323 \\
\hline \multicolumn{2}{r}{ Dumlah Rata-rata kelas } & 60,8 & 64,3 & 69,6 \\
\hline \multicolumn{2}{r}{ Daya Serap } & $61 \%$ & $64 \%$ & $70 \%$ \\
\hline
\end{tabular}

Ketentuan/pedoman untuk mengetahui kategori nilai adalah : peningkatan dengan menggunakan rentangan, serta

Tabel 6. Indikator Penilaian Hasil Belajar Aspek Penilaian Hasil Belajar

\begin{tabular}{|c|c|c|c|c|c|c|c|}
\hline \multirow[b]{3}{*}{ Rentang Nilai } & \multirow[b]{3}{*}{ Kategori } & \multicolumn{6}{|c|}{ Aspek Penilaian Hasil Belajar } \\
\hline & & \multicolumn{2}{|c|}{ Pra PTK } & \multicolumn{2}{|c|}{ Siklus I } & \multicolumn{2}{|c|}{ Siklus II } \\
\hline & & Jml Siswa & $\%$ & Jml Siswa & $\%$ & Jml Siswa & $\%$ \\
\hline $90-100$ & Sangat Baik & & & & & & \\
\hline $80-89,9$ & Baik & & & & & 2 & $11 \%$ \\
\hline $70-79,9$ & Cukup Baik & 3 & $16 \%$ & 6 & $31 \%$ & 6 & $31 \%$ \\
\hline $55-69,9$ & Cukup & 12 & $63 \%$ & 10 & $53 \%$ & 11 & $58 \%$ \\
\hline $40-54,9$ & Kurang & 4 & $21 \%$ & 3 & $16 \%$ & & \\
\hline $0-30,9$ & Sangat Kurang & & & & & & \\
\hline
\end{tabular}

\section{Pembahasan Penelitian}

Kemampuan interaksi, aktivitas belajar serta hasi belajar siswa setelah melihat data persiklus telah mengalami peningkatan yang baik, terbukti sebelum dilakukan penelitian tindakan kelas (PTK) hasil yang diperoleh belum optimal yaitu 1) ratarata daya serap nilai interaksi siswa adalah $54 \%$, setelah dilakukan PTK menjadi $65 \%$ (siklus I) dan $75 \%$ (siklus II); 2) nilai rata-rata minat siswa terhadap pelajaran PKn dari sebelum pra PTk yang hanya $59 \%$, pada siklus I meningkat menjadi $61 \%$ dan pada siklus ke II menjadi $75 \%$; 3) nilai ratarata sikap siswa juga mengalami peningkatan dari $57 \%$ sebelum diadakanya PTK, menjadi $61 \%$ pada PTK siklus I, dan $81 \%$ pada pelaksanaan pTK siklus II.

Pada hasil belajarpun mengalami peningkatan, kalau kita melihat dari data hasil belajar siswa serta membandingkan dari pra PTK, samapi dengan pelaksanaan siklus II sebagai kelanjutan dari pelaksanaan perbaikan dari siklus I, yang mana pada hasil belajar pada pra PTk siswa mendapatkan hasil belajar kategori kurang ada 4 orang $(21 \%)$, setelah melaksanakan PTK pada siklus I menjadi 3 orang (16\%) dan pada siklus II siswa yang tergolong nilai hasil pembelajarannya kurang menjadi 0 (0\%).

\section{SIMPULAN DAN SARAN \\ Simpulan}

Berdasarkan hasil PTK dengan penerapan model pembelajaran kooperatif dan Discovery, dapat disimpulkan sebagai berikut : (1) Penerapan model pembelajaran kooperatif dan Discovery dalam pelajaran PKn sangat perlu diterapkan karena dapat meningkatkan daya interaktif siswa terhadap siswa lain, serta siswa dengan guru di kelas V SDN Negeri 04 Pangkalan Buton, hal ini ditunjukkan dari data nilai rata-rata, nilai minimum maupun nilai maksimum dari pra PTK dengan Niali siklus I dan siklus II . (2) Aktivitas dan respon siswa terhadap model pembelajaran Kooperatif dan Discovery dalam pelajaran PKn kelas V di SDN 04 Pangkalan Buton ini tergolong positif. hal ini dapat diketahui dari hasil rata-rata penilaian proses pembelajaran dari segi minat serta sikap siswa yang meningkat dari pra PTK dan setelah dilaksanakannya siklus I dan siklus II. (3) 
Penerapan model pembelajaran Kooperatif dan Discovery dalam pelajaran PKn kelas V SDN 04 Pangkalan Buton dapat meningkatkan hasil belajar siswa, hal ini dapat dilihat dari hasil rata-rata penilaian hasil kerja siswa yang semakin meningkat dari siklus ke siklus berikutnya. (4) Penerepan model pembelajaran kooperatif dan discovery ini, sebagai seorang guru harus dapat menyesuaikan dengan materi ajar yang akan diajarkan terhadap siswa. karena melihat kelemahan yang ada yaitu tidak semua materi dapat menerapkan model pembelajaran ini. (5) Penerapan model pembelajaran kooperatif dan discovery ini secara kontinyu agar siswa terbiasa belajar dengan menggunakan model pembelajaran ini.

\section{Saran}

Berdasarkan hasil penelitian penulis dapat memberikan beberapa saran sebagai berikut : (1) Penerapan model pembelajaran Kooperatif dan Discovery ini perlu dikembangkan lagi dengan bantuan media pembelajaran berupa alat peraga lebih dari satu untuk setiap kali pertemuan pembelajaran. (2) Motivasi dari guru terhadap siswa, perlu ditingkatkan lagi agar kemampuan siswa dalam berinteraksi antar siswa, dengan guru menjadi lebih hidup, sehingga suasana belajar menjadi suatu pengalaman yang dapat diterapkan dilingkungan sekolah maupun di lingkungan masyarakat, karena siswa dapat lebih leluasa dalam menyampaikan ide / gagasan yang dimilikinya. (3) Dari pihak sekolah perlu memberikan dukungan pelaksanaan model pembelajaran Kooperatif dan Discovery ini, agar aktivitas dan krativitas serta hasil belajar siswa dapat lebih dikembangkan dalam kehidupan sehari-hari.

\section{DAFTAR PUSTAKA}

Adi w. Gunawan (2004). Genius learning strategi. Jakarta : PT. Gramedia pustaka utama.

Ali, Muhammad (1989). Penelitian Pendidikan Prosedur dan strategi. Bandung : Angkasa

Ibrahim, Muslmin,dkk ( 2000). Pembelajaran Kooperatif. Surabaya : Unesa University Press.

Permendiknas No. 22 Tahun 2006. Standar Isi. Jakarta : Menteri Pendidikan Nasional.

Permendiknas No. 41 Tahun 2007. Standar Proses untuk Satuan Pendidikan Dasar dan Menengah. Jakarta : Menteri Pendidikan Nasional.

Santyasa, I Wayan (2010). Teknik Penyusunan Proposal dan Laporan Penelitian Tindakan Kelas. Singaraja : Undiksha.

Wardhani,I.G.A.K, Wihardit (2009). Penelitian Tindakan Kelas. Cet9-Ed 1. Jakarta : Universitas Terbuka 